\title{
Studies on the mode of action of hexobendine,
}

\section{a prospective anti-anginal drug}

\author{
LINDA McINNES AND J. R. PARRATT
}

Department of Pharmacology, University of Strathclyde, Glasgow C.1

1. In cats anaesthetized with pentobarbitone sodium, hexobendine $(0 \cdot 25$ $\mathrm{mg} / \mathrm{kg}$ ) markedly increased myocardial blood flow (measured using a heat clearance technique) and usually decreased myocardial metabolic heat production, without influencing cardiac contractility or systemic arterial blood pressure. These effects lasted for about $45 \mathrm{~min}$.

2. Larger doses $(0.5$ and $1.0 \mathrm{mg} / \mathrm{kg})$ decreased systemic arterial blood pressure and the rate of rise of the left ventricular pressure pulse $(\mathrm{d} p / \mathrm{d} t)$, although left ventricular end-diastolic pressure was usually increased. This is indicative of a decrease in myocardial contractility.

3. In a concentration of $5 \times 10^{-6} \mathrm{~g} / \mathrm{ml}$., hexobendine protected isolated rabbit atria against the decrease in contractility that follows the removal of oxygen.

4. Hexobendine did not antagonize the systemic and myocardial effects of infusions of adrenaline and noradrenaline, nor (except in concentrations of $10^{-5} \mathrm{~g} / \mathrm{ml}$.) the increase in contractility induced by these catecholamines on isolated rabbit atria.

The prospective anti-anginal drug hexobendine (N, $\mathrm{N}^{\prime}$-dimethyl-N, $\mathrm{N}^{\prime}$-bis[3-(3,4,5-trimethoxybenzoxy)propyl]ethylenediamine dihydrochloride, Ustimon, ST 7090) was the most active of a series of polymethylenediamine derivatives investigated by Heistracher, Kraupp \& Schiefthaler (1964). It was found to increase coronary flow in the isolated heart and to increase coronary sinus $\mathrm{pO}_{2}$ in anaesthetized dogs in doses which had almost no effect on systemic arterial blood pressure or heart rate (Kraupp, Heistracher, Wolner \& Tuisl, 1964). In a further study, Kraupp and his colleagues concluded that in the dog, increases in coronary sinus outflow and cardiac work occur with either small decreases in, or no effect on, myocardial oxygen consumption, although oxygen availability is markedly improved. This finding apparently indicates an increase in aerobic cardiac efficiency (Kraupp, Wolner, Adler-Kastner, Chirikdjian, Ploszczanski \& Tuisl, 1966).<smiles>COc1cc(C(=O)OCCNCCCNCCNCCOC(=O)c2cc(OC)c(OC)c(OC)c2)cc(OC)c1OC</smiles> 
Recently it has been suggested that the beneficial effects of the organic nitrates and nitrites, and of $\beta$-adrenoceptor blocking drugs, in angina pectoris can be explained by their effect on myocardial metabolic heat production (Parratt, 1969a). Thus amyl nitrite (Grayson, Irvine \& Parratt, 1967) markedly decreases myocardial metabolic heat production and the $\beta$-adrenoceptor blocking drugs propranolol (Parratt, 1969b) and H 56/28 (Parratt \& Wadsworth, unpublished) antagonize increases in heat production induced by catecholamines. It seemed possible that the increase in aerobic cardiac efficiency observed by Kraupp and his colleagues with hexobendine might be explained by changes in metabolic heat production and this has been examined in anaesthetized cats. In addition, a more detailed study has been undertaken concerning the effects of hexobendine on myocardial contractility and attempts have also been made to assess its effect on the tolerance of isolated cardiac tissue to anoxia.

\section{Methods}

\section{Anaesthetized cats}

Cats of either sex and weighing between 2 and $3.5 \mathrm{~kg}$ were anaesthetized with sodium pentobarbitone $(30 \mathrm{mg} / \mathrm{kg}$ by intraperitoneal injection). The operating table was heated to maintain body temperature between $36.5^{\circ}$ and $37.5^{\circ} \mathrm{C}$. This was checked by direct recording thermocouples in the rectum, the aortic arch and the mid-oesophagus. The trachea was cannulated and positive pressure ventilation commenced at thoracotomy with room air. This was usually continued throughout the experiment in order to eliminate changes in heat loss from the surface of the heart. Blood flow in the left myocardium was measured using a modification of the method of Grayson \& Mendel (1961), the heated thermocouple being introduced into the muscle mass mainly supplied by the descending branch of the left coronary artery. The method described in detail in previous publications (Parratt, 1964 ; Grayson, Irvine \& Parratt, 1967), has been modified as follows. In place of the cam operated switch gear and 6V battery (Carlyle \& Grayson, 1956 ; Dosekun, Grayson $\&$ Mendel, 1960), a mains operated automatic electronic switch gear unit was used which enabled timing of any of three selected currents $\left(0.200,0.315\right.$ and $\left.0.600 \mathrm{~A}^{2}\right)$ to be selected for a period of 0 to $99 \mathrm{sec}$. In general the times were those used by Carlyle \& Grayson (1956). The unit has the advantage that variations in applied current throughout the experiment are negligible. The output from the recording leads of the thermocouple was fed directly into a Kipp and Zonen micrograph BD5 ink writing recorder ( 100 or $200 \mu \mathrm{V}$ for a full scale deflection of $20 \mathrm{~cm})$ at a paper speed of $10 \mathrm{~mm} / \mathrm{min}$. The cold (reference) junction of the thermocouple was inserted by way of the right carotid artery into the aortic arch together with a direct recording (unheated copper-constantan) thermocouple (Ellab thermocouple-applicator type F6). This enabled the absolute temperature of the myocardium to be monitored. At the commencement of the experiments (after allowing for temperature equilibration following suturing of the chest wall) the myocardium was hotter than the aortic blood by $0.2^{\circ}-0.7^{\circ} \mathrm{C}$.

Myocardial thermal conductivity increment (the difference between the apparent thermal conductivity of tissue with blood flowing and tissue with no blood flowing) is an approximately linear function of local flow around the thermocouple and was calculated as previously described (Grayson \& Mendel, 1961; Parratt, 1964 ; 
Grayson \& Parratt, 1966 ; Parratt, 1969b). All the results described in this paper were obtained by feeding measured values of $\theta$ and $t$ (temperature increments induced by a heating current of $0 \cdot 115$ and $0.200 \mathrm{~A}^{2}$ respectively and obtained from the myocardial temperature record), into an IBM computer which printed out values for thermal conductivity increment, an index of myocardial blood flow, and " corrected temperature", an index of local myocardial metabolic heat production (Dosekun, Grayson \& Mendel, 1960 ; Parratt, 1969b).

Arterial blood pressure was recorded from the left femoral artery or from a brachial artery using either a polyethylene or short steel catheter and a capacitance pressure transducer (Elema-Schönander EMT 35). Mean pressure was obtained by integration. Left intraventricular pressure was recorded with another capacitance transducer (Elema-Schönander EMT 34, which has a displacement of $0.03 \mathrm{~mm}^{3} / 100$ $\mathrm{mm} \mathrm{Hg}$ ) using a metal catheter similar to that described by Benfey, Greef \& Heeg (1967). This was introduced by way of the right carotid artery and through the aortic valves, the pressure being continually monitored with an oscilloscope. With practice it was possible to manoeuvre the catheter so that the lumen was never obstructed, at any point in the cardiac cycle, by the contracting muscle. To permit the accurate determination of end-diastolic pressure (LVEDP) the intraventricular pressure record was cut off above $30 \mathrm{~mm} \mathrm{Hg}$. The rate of rise of intraventricular pressure with time $(\mathrm{d} p / \mathrm{d} t)$ was continuously determined with an analogue differentiator circuit similar to that described by Schaper, Lewi \& Jageneau (1965) and by Linden (personal communication).

Left ventricular pressure, left ventricular end-diastolic pressure, arterial pressure, right atrial pressure, $\mathrm{d} p / \mathrm{d} t$ and the e.c.g. (leads II or III) were recorded on an eight channel Elema-Schönander recorder (Mingograph 81), the galvanometers of which respond to a frequency of $500 \mathrm{c} / \mathrm{s}$. Myocardial blood flow and intraventricular pressure were not measured in the same group of animals.

Hexobendine in doses of $0.25,0.5$ and $1.0 \mathrm{mg} / \mathrm{kg}$ was injected by way of a polyethylene catheter in the left femoral vein. Infusions of adrenaline and noradrenaline $(0.25$ to $1.0 \mu \mathrm{g} / \mathrm{kg}$ per min) were given before and after hexobendine using a Sage motorized syringe delivering $0.6 \mathrm{ml} . / \mathrm{min}$.

\section{Isolated rabbit atria}

The effects of hexobendine were studied on spontaneously beating rabbit atria in Ringer-Locke solution at $33^{\circ} \mathrm{C}$, using an isometric strain-gauge, a Ugo-Basile microdynamometer and a moving-coil galvanometer writing on a smoked drum. Log-dose response curves were obtained with adrenaline and noradrenaline in the presence of varying concentrations of hexobendine. The effect of hexobendine on the recovery of isolated atria from anoxia was initially studied by the method described by Penn (1965) but it was later felt to be more relevant to examine whether or not hexobendine modified the resistance of isolated atria to anoxia rather than recovery from anoxia. This was studied in the following manner. Isolated atria were set up in Ringer-Locke solution gassed with $97 \%$ oxygen and $3 \%$ carbon dioxide and left to stabilize for about an hour. The gas mixture was then changed to $97 \%$ oxygenfree nitrogen and 3\% carbon dioxide and the time taken for the force of contraction to reach $80 \%, 50 \%$ and $25 \%$ of the pre-anoxic value noted; the total number of beats during each of these periods was also calculated. On reverting to oxygen the force of contraction recovered rapidly to the control level and this recovery time 
was also measured. After a further 15-20 min rest period a second period of anoxia was introduced. In any given preparation the time taken to reach $80 \%, 50 \%$ and $25 \%$ of the pre-anoxic level in the second period of anoxia was very similar to that in the first period. The effect of anoxia was then studied in the presence of hexobendine ( 2 and $5 \mu \mathrm{g} / \mathrm{ml}$.), for two periods of anoxia, and again after washing out the hexobendine.

\section{Results}

\section{Effects of hexobendine on myocardial blood flow and metabolic heat production}

In nine cats the myocardial thermal conductivity ranged from 12.7 to 21.8 c.g.s. units $\times 10^{-4}$, although six of these animals had values between 16.6 and 18.0 units. The mean thermal conductivity increment was $4.8 \times 10^{-4}$ units, indicating that in the cat, myocardial blood flow is similar to that in the monkey, the baboon and the dog (see Parratt, 1969b). After the injection of hexobendine $(0.25 \mathrm{mg} / \mathrm{kg})$ the conductivity values ranged from $14 \cdot 1$ to 41.6 and the conductivity increment values from 1.9 to 29.4 c.g.s. units $\times 10^{-4}$, an increase of blood flow between 34 and $810 \%$ (mean of $98 \%$ ). Myocardial blood flow increased in eight out of the nine experiments and lasted for between 40 and $65 \mathrm{~min}$. As there were also slight decreases in mean systemic arterial pressure it is clear that hexobendine markedly reduces resistance to flow in the myocardial vascular bed (Table 1).

Heart rate was initially decreased from the pre-injection level of $189 \pm 9$ beats $/ \mathrm{min}$ by a mean of 23 beats/min. This recovered to a mean of 179 beats $/ \mathrm{min}$ within 5 min of the injection. Metabolic heat production (myocardial "corrected temperature") was measured in seven of the experiments. In two of these it was slightly increased $\left(+0.04\right.$ and $\left.+0.03^{\circ} \mathrm{C}\right)$ but in the other five cats a considerable depression of myocardial metabolic heat production was observed. This ranged from -0.07 to $-0.32^{\circ} \mathrm{C}$ (mean, for these five cats, of $-0 \cdot 15^{\circ} \mathrm{C}$ ). The effect of two successive injections of hexobendine on myocardial blood flow and heat production is illustrated in Fig. 1.

\section{Haemodynamic effects of hexobendine in anaesthetized cats}

Three doses of hexobendine were chosen; a dose $(0.25 \mathrm{mg} / \mathrm{kg})$ which we had previously shown substantially increased myocardial blood flow, and two higher doses $(0.5$ and $1.0 \mathrm{mg} / \mathrm{kg})$ in view of the observation of Irvine \& Parratt (unpublished) that in dogs with an implanted myocardial thermocouple similar doses markedly decreased systemic arterial pressure. The detailed results are shown in Table 2 and Fig. 2. Hexobendine lowered systolic and diastolic arterial pressures and systolic intraventricular pressure (Fig. 3). The maximum rate of rise of left intraventricular pressure (positive $\mathrm{d} p / \mathrm{d} t$ ) was consistently decreased (mean of $11 \%$ with a dose of $0.25 \mathrm{mg} / \mathrm{kg} ; 18 \%$ with a dose of $0.5 \mathrm{mg} / \mathrm{kg}$ ) despite a tendency for an increase in LVEDP (Fig. 2). An increase in LVEDP of this magnitude would be expected to increase $\mathrm{d} p / \mathrm{d} t$ (the Frank-Starling effect). The combination of a decreased positive $\mathrm{d} p / \mathrm{d} t$ max. and a raised LVEDP indicates a decrease in contractility. The rate of fall of intraventricular pressure (negative $\mathrm{d} p / \mathrm{d} t \max$.) was also decreased by these doses of hexobendine.

In unpublished experiments in dogs, Irvine \& Parratt found that a $0.4 \mathrm{mg} / \mathrm{kg}$ dose of hexobendine sometimes produced quite sustained decreases in mean systemic 
TABLE 1. Effect of hexobendine $(0.25 \mathrm{mg} / \mathrm{kg}$, intravenously) on myocardial blood flow and vascular resistance in cats

Mean blood pressure (MBP) ( $\mathrm{mm} \mathrm{Hg}$ )

Heart rate (beats'min)

Myocardial blood flow (MBF) (conductivity increment, c.g.s. units $\times 10^{-4}$ )

Mean vascular resistance (MBP/MBF; arbitrary units)

$$
\begin{gathered}
\text { Control } \\
106 \pm 9 \\
(82-160) \\
189 \pm 9 \\
(132-228) \\
4 \cdot 8 \pm 0 \cdot 9 \\
(0 \cdot 5-9 \cdot 6)
\end{gathered}
$$

$$
\begin{gathered}
22 \cdot 1 \pm 9 \cdot 3 \\
(13-41)
\end{gathered}
$$

\begin{tabular}{|c|c|c|c|c|c|c|c|c|}
\hline \multirow{3}{*}{$\begin{array}{c}\text { Experi- } \\
\text { ment }\end{array}$} & \multirow{3}{*}{$\begin{array}{l}\text { Heart rate } \\
\text { (beats } / \mathrm{min} \text { ) }\end{array}$} & \multirow{2}{*}{\multicolumn{3}{|c|}{$\begin{array}{r}\text { Femoral arterial } \\
\text { pressure }(\mathrm{mm} \mathbf{H g})\end{array}$}} & \multicolumn{2}{|c|}{$\begin{array}{l}\text { Left ventricular } \\
\text { pressure (mm Hg) }\end{array}$} & \multirow{2}{*}{\multicolumn{2}{|c|}{$\begin{array}{c}\text { Peak dp/d } t \\
(\mathrm{~mm} \mathrm{Hg} / \mathrm{sec})\end{array}$}} \\
\hline & & & & & \multirow{2}{*}{$\begin{array}{c}\text { Peak } \\
\text { systolic }\end{array}$} & \multirow{2}{*}{$\begin{array}{l}\text { End- } \\
\text { diastolic }\end{array}$} & & \\
\hline & & Systolic & Diastolic & Mean & & & +ve & $-v e$ \\
\hline 1 & $\begin{array}{l}190 \\
190\end{array}$ & $\begin{array}{l}118 \\
106\end{array}$ & $\begin{array}{l}76 \\
56\end{array}$ & $\begin{array}{l}90 \\
73\end{array}$ & $\begin{array}{r}102 \\
90\end{array}$ & $\begin{array}{l}5 \\
4\end{array}$ & $\begin{array}{l}4400 \\
3800\end{array}$ & $\begin{array}{l}3650 \\
3250\end{array}$ \\
\hline 2 & 200 & 144 & 96 & 112 & 122 & 8 & 5100 & 2900 \\
\hline & 200 & 144 & 100 & 115 & 114 & 8 & 4700 & 2700 \\
\hline 3 & 220 & 204 & 88 & 134 & 148 & 8 & 4600 & 3800 \\
\hline & 192 & 180 & 58 & 98 & 120 & 12 & $\Xi 8 C 0$ & 2700 \\
\hline 4 & 208 & 202 & 76 & 126 & 140 & 2 & 4500 & 3650 \\
\hline & 192 & 196 & 60 & 112 & 128 & 4 & 3800 & 3150 \\
\hline 5 & 180 & 146 & 92 & 120 & 106 & $7 \cdot 5$ & 3000 & - \\
\hline & 180 & 138 & 64 & 91 & 92 & 10 & 3000 & - \\
\hline
\end{tabular}

$$
\begin{array}{cc}
\text { After hexobendine } & \% \text { change } \\
93 \pm 8 & -12 \% \\
(68-142) & \\
179 \pm 8 & -5 \% \\
(136-220) & \\
9 \cdot 5 \pm 2 \cdot 6 & +98 \% \\
(1 \cdot 9-29 \cdot 4) & \\
13 \cdot 1 \pm 9 \cdot 1 & -41 \% \\
(5-36) &
\end{array}
$$

Values are the means of nine experiments \pm S.E. of the mean; range in brackets.

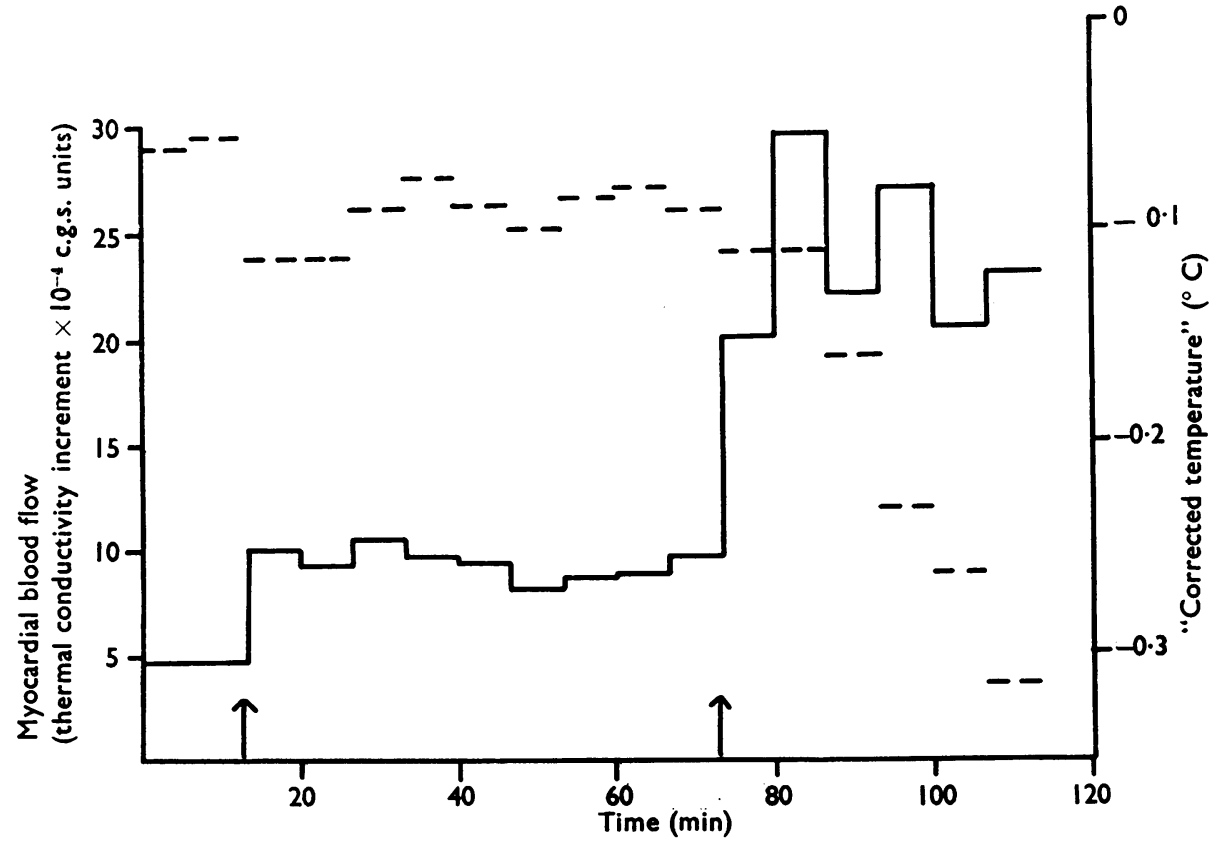

FIG. 1. Effect of two injections of hexobendine $(0.25 \mathrm{mg} / \mathrm{kg}$; at the arrows) on myocardial blood flow (as thermal conductivity increment, $\Delta k \times 10^{-4}$ c.g.s. units; continuous line) and on myocardial metabolic heat production (as "corrected temperature" ( $\left.{ }^{\circ} \mathrm{C}\right)$; broken line) in a cat weighing $2 \cdot 6 \mathrm{~kg}$.

TABLE 2. Haemodynamic studies before and after hexobendine $(0.25 \mathrm{mg} / \mathrm{kg}$, intravenously) in cats 
(a)

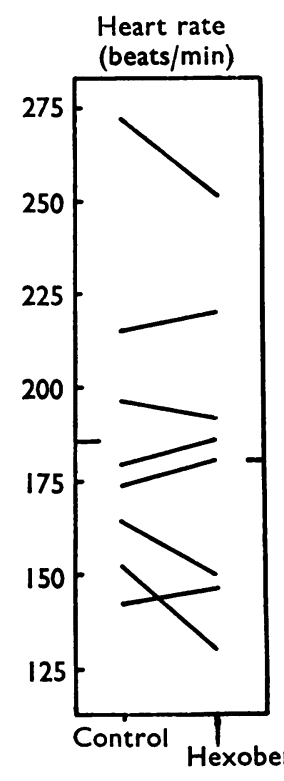

Femoral arterial pressure $(\mathrm{mm} \mathrm{Hg}$ )

Systolic

Diastolic

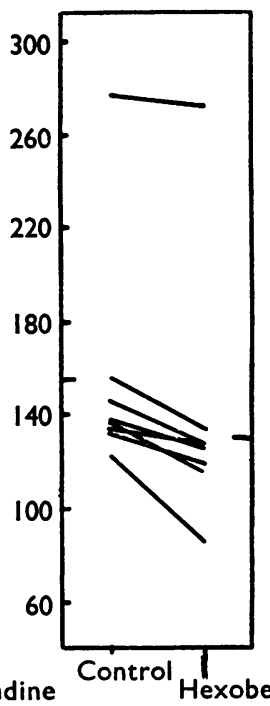

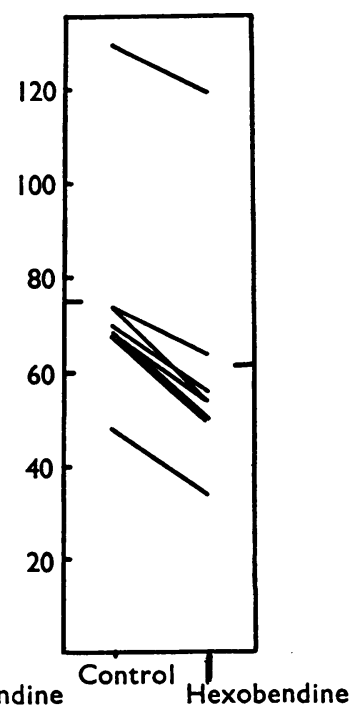

(b)
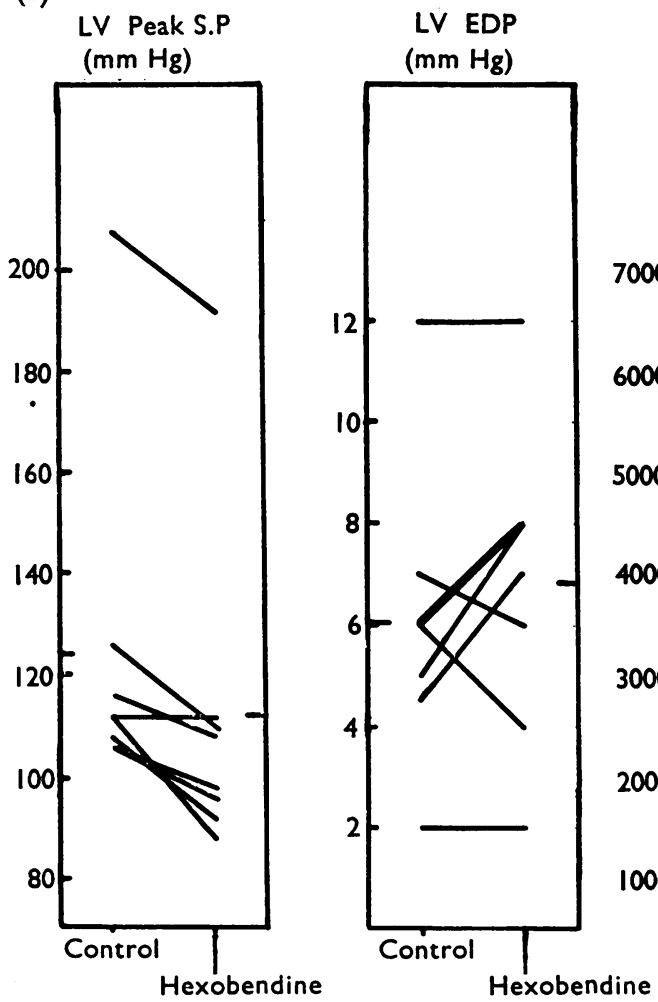

Peak positive $d p / d t$

Peak negative $d p / d t$ ( $\mathrm{mm} \mathrm{Hg} / \mathrm{sec}$ )

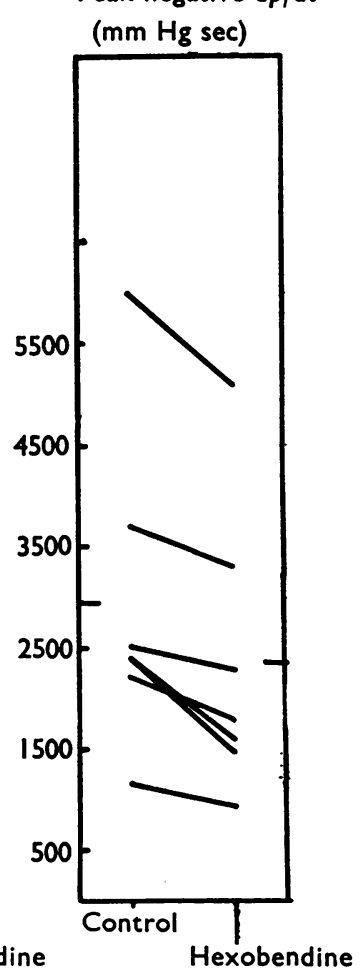

FIG. 2. a : Effect of hexobendine $(0.5 \mathrm{mg} / \mathrm{kg})$ on heart rate and on femoral arterial systolic and diastolic blood pressures in cats. The means of each group are represented by the short horizontal lines. b: Changes in various indices of contractility in cats before and after the injection of hexobendine $(0.5 \mathrm{mg} / \mathrm{kg})$. The means of each group are represented by the short horizontal lines. 
pressure with little subsequent recovery. In cats, hypotension and the decrease in $\mathrm{d} p / \mathrm{d} t$ never lasted longer than $25 \mathrm{~min}$-much less than the period of increased myocardial blood flow. In two cats given doses of $1.0 \mathrm{mg} / \mathrm{kg}$, systemic arterial hypotension was still marked $30 \mathrm{~min}$ after the injection. Doses of hexobendine up to $1.0 \mathrm{mg} / \mathrm{kg}$ did not influence the effect of infusions of adrenaline and noradrenaline $(0.25$ to $1.0 \mu \mathrm{g} / \mathrm{kg}$ per $\mathrm{min})$ on myocardial blood flow, sytemic arterial pressure, intraventricular pressure or $\mathrm{d} p / \mathrm{d} t$.

\section{Effect of hexobendine on the response of isolated rabbit atria to anoxia}

Twenty experiments were performed on ten preparations. In concentrations of $2 \times 10^{-6} \mathrm{~g} / \mathrm{ml}$., hexobendine had no effect on the responses of isolated atria to anoxia. With a concentration of $5 \times 10^{-6} \mathrm{~g} / \mathrm{ml}$., however, there was usually a clear protective effect ; that is, the time taken for contractile force to be reduced to $80 \%, 50 \%$ and $25 \%$ of the pre-anoxic values was considerably longer in the presence of this concentration of hexobendine (Fig. 4). This effect was largely reversible on returning the atrial preparations to normal Locke Ringer (Fig. 4). Hexobendine, in the concentrations used in this study, had no effect on the rate or force of contraction of spontaneously beating rabbit atria over a contact period of $15 \mathrm{~min}$, neither did it influence the rate of beating of atrial preparations subjected to anoxia.

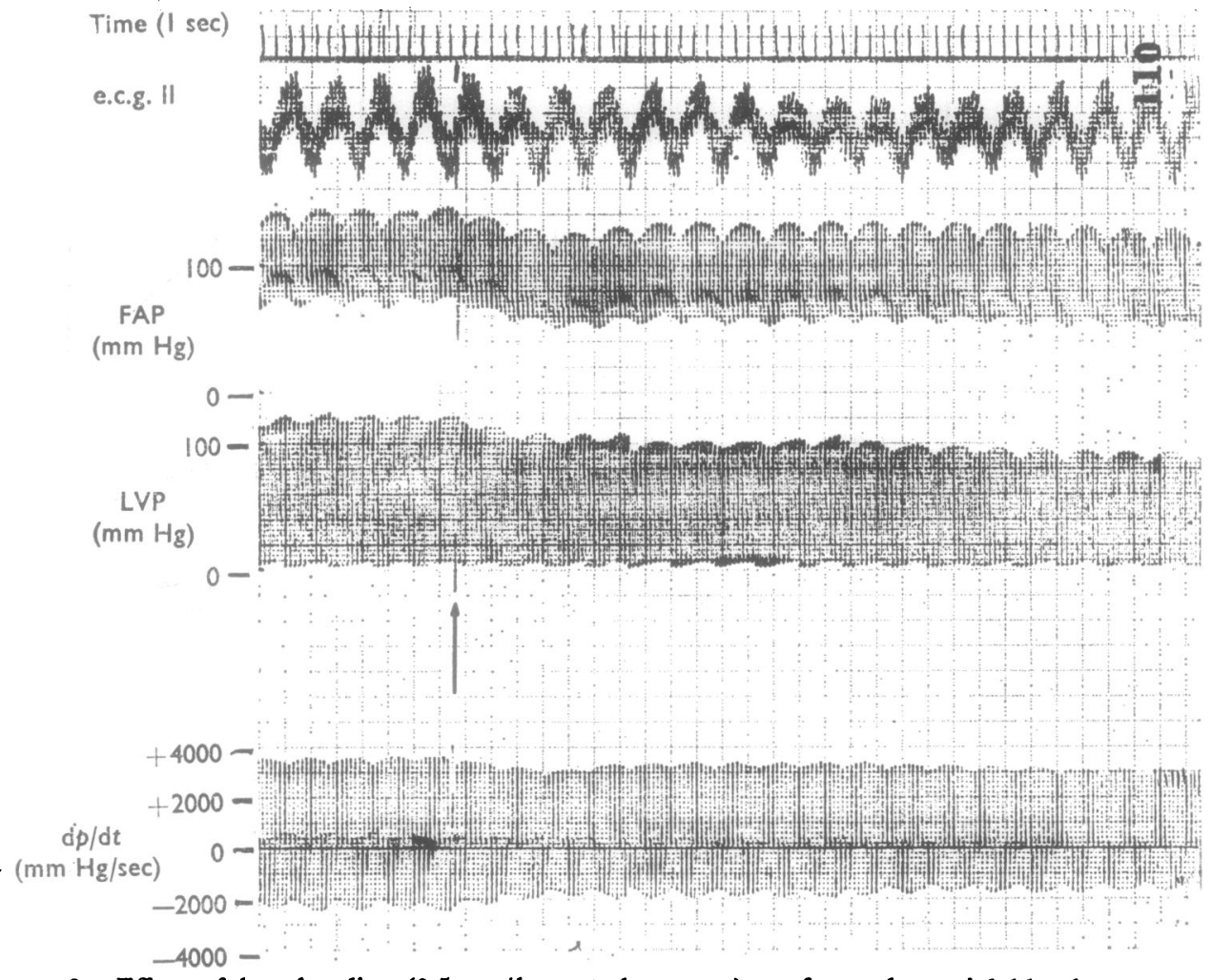

FIG. 3. Effect of hexobendine $(0.5 \mathrm{mg} / \mathrm{kg}$; at the arrow) on femoral arterial blood pressure (FAP), left ventricular pressure (LVP) and $\mathrm{d} p / \mathrm{d} t$ in a $3 \mathrm{~kg}$ cat. 
Effect of hexobendine on the response of isolated rabbit atria to adrenaline and noradrenaline

In sixteen preparations log-dose response curves were obtained to adrenaline and noradrenaline in concentrations of $5 \times 10^{-8}$ to $10^{-6} \mathrm{~g} / \mathrm{ml}$. The isometric tension curves were displaced to the right only by concentrations of hexobendine exceeding $10^{-5} \mathrm{~g} / \mathrm{ml}$. but the chronotropic effects of the catecholamines were markedly reduced

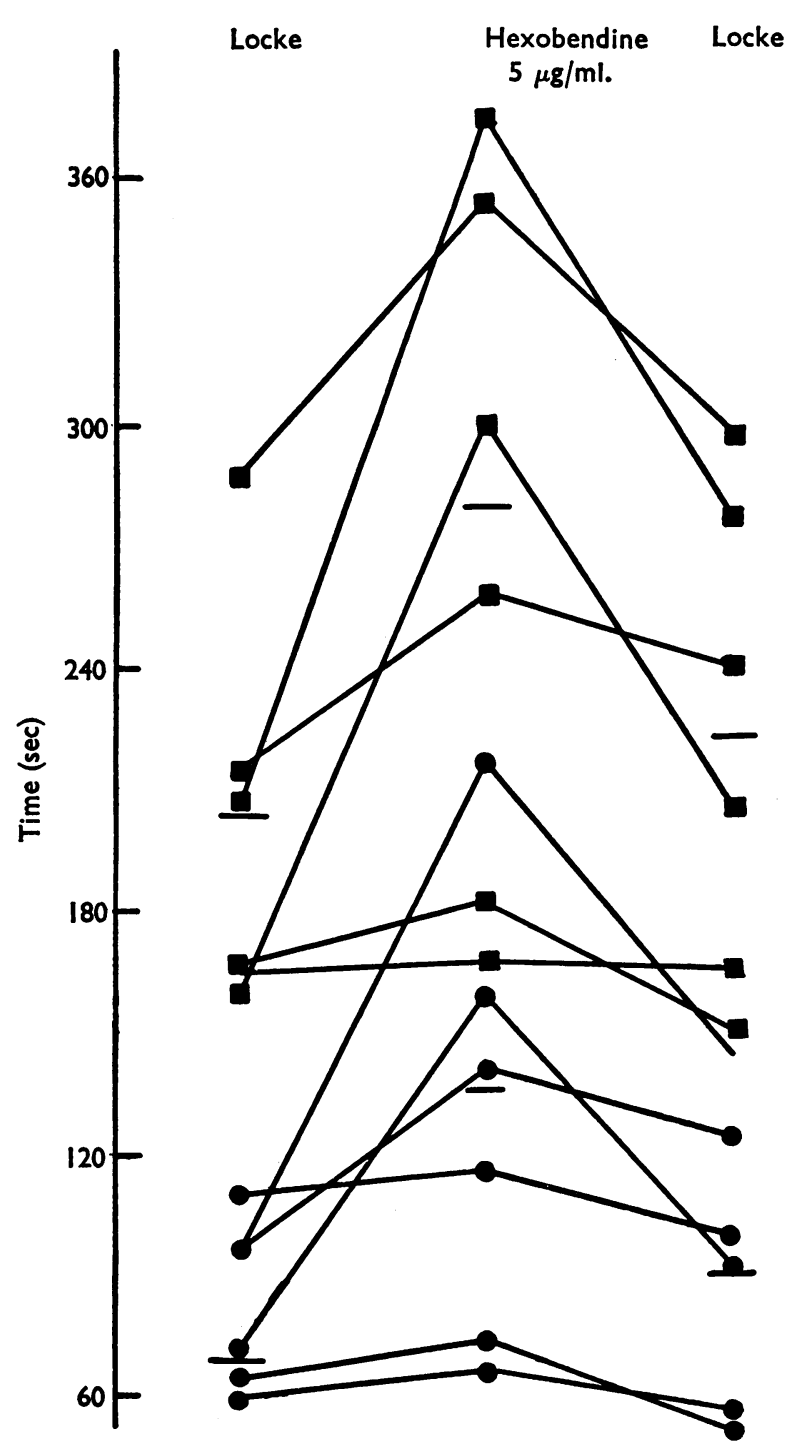

FIG. 4. Effect of hexobendine $(5 \mu \mathrm{g} / \mathrm{ml}$.) on the time taken (sec) for isolated spontaneously beating rabbit atria to reach $80 \%$ ( ) and $25 \%$ of their initial contractile force when subjected to anoxia. The corresponding times taken in Ringer-Locke solution before introducing hexobendine and after washing out the hexobendine are shown on the left and right respectively. Each symbol is the mean of two experiments in the same preparation and the means of all the experiments are indicated by the short horizontal bars. 
by hexobendine in concentrations of $2.5 \times 10^{-6} \mathrm{~g} / \mathrm{ml}$. and completely abolished at a concentration of $10^{-5} \mathrm{~g} / \mathrm{ml}$.

\section{Discussion}

In recent years a considerable reappraisal has taken place of the properties necessary for an effective anti-anginal drug. Previously drugs had been introduced into clinical practice purely on the basis of an ability to increase total coronary flow in anaesthetized animals and, in general, most drugs which possess this property have proved disappointing when applied to the clinical situation. The view has been put forward by McGregor \& Fam (1966) that, since coronary arteriolar dilatation in anginal patients is probably maximal, vasodilator drugs acting mainly at arteriolar level would in fact reduce flow in the ischaemic region of the myocardium although flow in healthy regions would increase. There are in fact good experimental reasons for believing that the ability of a drug to increase blood flow in the healthy myocardium is largely irrelevant to the problem of assisting the myocardial oxygen imbalance which is the main feature of the patient with angina pectoris (see Parratt, 1969a). There are, however, other ways in which this problem can be approached, quite apart from attempting to improve oxygen availability (Parratt, 1969a ; 1969c). One is to reduce the metabolic requirements of the myocardium by reducing cardiac work (for example, with suitable $\beta$-adrenoceptor blocking drugs), another is to reduce that part of myocardial energy lost as heat (Grayson et al., 1967) and a third is to protect in some way the cardiac contractile elements from the effects of oxygen lack.

In the present studies the finding of Kraupp et al. (1966) that hexobendine increases coronary flow has been confirmed by the measurement of local flow in the myocardial muscle mass. Hexobendine markedly increased myocardial blood flow in doses having little effect on myocardial contractility or on systemic haemodynamics and this improvement of local flow lasted for up to $45 \mathrm{~min}$. It would perhaps be more pertinent to know if hexobendine increased flow in an ischaemic area of myocardium and, although this has not been attempted in the present study, some as yet unpublished observations (Ledingham, Parratt \& Vance) in dogs suggest that hexobendine does not, in fact, do this. In these experiments a Sones catheter was introduced under fluoroscopic control into the left circumflex branch of the coronary artery of dogs until electrocardiographic evidence of myocardial ischemia was obtained. In these conditions hexobendine did not increase blood flow in the region supplied by this artery (using a radioactive xenon technique) although the coronary sinus $\mathrm{pO}_{2}$ was considerably increased, perhaps indicating an increase in flow in the non-ischaemic area of myocardium. Thus, although the cat experiments clearly indicate an ability of hexobendine markedly to increase flow in the normal myocardium, it is not justifiable to conclude from this evidence alone that flow in the myocardium of anginal patients would be similarly improved.

Probably more relevant to the situation in the anginal patient are the findings that hexobendine usually markedly depressed metabolic heat produced by the myocardium (Fig. 1) and protected isolated cardiac muscle from the decrease in contractility which follows complete anoxia. Decreases in metabolic heat production of the order found in these studies and in the absence of marked changes in oxygen consumption, which from the evidence of Kraupp et al. (1966) is unlikely, would seem to indicate an increase in cardiac efficiency since the amount of energy lost as 
heat is greatly reduced. A similar effect has been noted with amyl nitrite (Grayson et al., 1967).

The method described for studying the effect of drugs on the response of isolated myocardial tissue to anoxia is relatively simple and, moreover, it was possible to recover atrial preparations from five or six periods of anoxia without difficulty. We found, as did Gardner \& Farah (1954), that the contractile mechanism was more sensitive to oxygen lack than the rate of beating and obtained more reproducible results with this "protective" method than with initial experiments using the method described by Penn (1965). Since the protective effect was only seen with concentrations of hexobendine rather greater than those one would expect to find in the blood after an injection of $0.25 \mathrm{mg} / \mathrm{kg}$, it is not established whether these results on an isolated cardiac preparation have any relevance to a possible therapeutic mechanism in man.

In doses larger than those required to increase myocardial blood flow, hexobendine was found to decrease systemic blood pressure and to decrease the rate of rise of left ventricular pressure $(\mathrm{d} p / \mathrm{d} t)$. Hamacher (1960) has suggested the continuous electronic differentiation (or on-line computation) of this pressure pulse to be a relatively simple method of assessing cardiac contractility. This maximum rate of ventricular pressure change is determined by $(a)$ the force of contraction of the contractile elements and $(b)$ the end-diastolic dimensions (and hence pressure) of the ventricle (Reeves, Hefner, Jones, Coghlan, Prieto \& Carroll, 1960 ; Schaper et al., 1965). In the present experiments hexobendine decreased $\mathrm{d} p / \mathrm{d} t$ max. and usually increased LVEDP. One must conclude therefore that, at these dose levels, hexobendine is decreasing myocardial contractility. This would be partially responsible for the observed sustained hypotension, though a general vasodilator action also seems likely. In their earlier studies, Kraupp et al. (1966) found that, in doses up to $1.0 \mathrm{mg} / \mathrm{kg}$, hexobendine transiently increased cardiac output in dogs anaesthetized with urethane and chloralose without affecting systemic blood pressure. In a more recent report, however (Kraupp, Grossmann, Stühlinger \& Raberger, 1968), quite marked and sustained decreases in systemic blood pressure were described in dogs anaesthetized with sodium pentobarbitone given considerably smaller doses $(0.3$ $\mathrm{mg} / \mathrm{kg}$ ) of hexobendine, a finding which we, too, have observed in similar conditions.

We thank the Medical Research Council for financial support for one of us (L. M.), the Wellcome Trust for a substantial grant for apparatus and Beecham Research Laboratories for the hexobendine and for a grant for apparatus. We are also grateful to Mr. Ken Carter and his colleagues at the Western Regional Hospital Board Physics Department who designed and made the heating circuit and to Mr. Alex Hay who made the differentiating circuit.

\section{REFERENCES}

Benfey, B. G., GreEFF, K. \& HeEg, E. (1967). Evaluation of sympathetic beta-receptor blockade by recording the rate of ventricular pressure rise in cats. Br.J. Pharmac. Chemother., 30, 23-29.

Carlyle, A. \& Grayson, J. (1956). Factors involved in the control of cerebral blood flow. $J$. Physiol., Lond., 133, 10-30.

Dosekun, F. O., Grayson, J. \& Mendel, D. (1960). The measurement of metabolic and vascular responses in liver and muscle with observations on their responses to insulin and glucose. $J$. Physiol., Lond., 150, 581-606.

Gardner, E. A. \& Farah, A. (1954). The action of some enzyme inhibitors on the isolated rabbit auricle. J. Pharmac. exp. Ther., 111, 255-264.

Grayson, J., Irvine, Mona \& Parratt, J. R. (1967). The effects of amyl nitrite inhalation on myocardial blood flow and metabolic heat production. Br. J. Pharmac. Chemother., 30, 488-496. 
Grayson, J. \& Mendel, D. (1961). Myocardial blood flow in the rabbit. Am. J. Physiol., 200, 968-974.

Grayson, J. \& Parratt, J. R. (1966). A species comparison of the effects of changing perfusion pressure on blood flow and metabolic heat production in the myocardium. J. Physiol., Lond., $187,465-488$.

HAMACHER, J. (1960). Die Steilheit des intracardialen Druckanstieges in der isometrischen Phase der spontanen Herzaktion als Kriterium einer pharmakologischen Wirkungsanalyse am Warmblüterherzen in situ. Naunyn-Schmiedebergs Arch. exp. Path. Pharmak., 238, 73-75.

Heistracher, P., KraupP, O. \& Schiefthaler, T. (1964). Pharmakodynamische Eigenschaften von Diestern der Trimethoxy-bzw. Triaethoxybenzoesaure mit Hydroxyalkyl-substituierten Diaminen. Arzneimittel-Forsch., 14, 1077-1086.

Kraupp, O., Grossmann, W., Stưhlinger, W. \& Raberger, G. (1968). Die Wirkung von Hexobendin auf die arterielle und coronarvenöse $\mathrm{CO}_{2}$-Spannung und Wasserstoffionenkonzentration am Hund. Arzneimittel-Forsch., 18, 1067-1073.

Kraupp, O., Heistracher, P., Wolner, E. \& Tuisl, E. (1964). Die Wirkung von N,N'-DimethylN,N'-bis-[3-(3',4',5'-trimethoxybenzoxy)-propyl]-äthylendiamin auf Herz-und Kreislaufdynamik sowie $\mathrm{O}_{2}$-Versorgung des Herzmuskels und des Gehirnes. Arzneimittel-Forsch., 14, 1086-1098.

Kraupp, O., Wolner, E., Adler-Kastner, L., Chirikdian, J. J., Ploszczanski, B. \& Tuisl, E. (1966). 'Die Wirkung von Hexobendin auf Sauerstoffverbrauch, Energetik und Substratstoffwechsel des Herzens. Arzneimittel-Forsch., 16, 692-696.

MCGREGOR, M. \& FAM, W. M. (1966). Regulation of coronary blood flow. Bull. N.Y. Acad. Med., 42, 940-950.

Parratt, J. R. (1964). A comparison of the effects of the plasma kinins, bradykinin and kallidin, on myocardial blood flow and metabolism. Br.J. Pharmac. Chemother., 22, 34-46.

Parratt, J. R. (1969a). Some aspects of the pharmacology of prospective anti-anginal drugs. Acta Cardiol., in the Press.

Parratt, J. R. (1969b). The effect of adrenaline, noradrenaline and propranolol on myocardial blood flow and metabolic heat production in monkeys and baboons. Cardiovasc. Res., 3, in the Press.

Parratt, J. R. (1969c). Pharmacological aspects of the coronary circulation. In Progress in Medicinal Chemistry, ed. Ellis, G. P. \& West, G. B., vol. 6, pp. 11-66. London: Butterworths.

PENN, R. G. (1965). Some factors influencing the recovery of isolated myocardium from acute anoxia. Br. J. Pharmac. Chemother., 24, 253-265.

Reeves, T. J., Hefner, L. L., Jones, W. B., Coghlan, C., Prieto, G. \& Carroll, J. (1960). The hemodynamic determinants of the rate of change of pressure in the left ventricle during isometric contraction. Am. Heart J., 60, 745-761.

Schaper, W. K. A., Lewi, P. \& JAGeneau, A. H. M. (1965). The determinants of the rate of change of the left ventricular pressure (dp/dt). Arch. Kreislaufforsch., 46, 27-41.

(Received April 9, 1969) 